\title{
Human Anticancers and Antidiabetic Activities of the Cyanobacterium Fischerella sp. BS1-EG Isolated from River Nile, Egypt
}

\author{
Bassant E. Ahmed ${ }^{1}$, Mona H. Badawi ${ }^{1}$, Soha S. Mostafa ${ }^{2}$ and Aziz M. Higazy ${ }^{1 *}$ \\ ${ }^{1}$ Department of Microbiology, Fac. Agric., Cairo University, Giza, Egypt \\ ${ }^{2}$ Department of Microbiology, Inst. Soil, Water and Environment, ARC, Giza, Egypt \\ *Corresponding author
}

\begin{abstract}
A B S T R A C T
Cyanobacteria are known as a potential source of several metabolic compounds like phytohormons, phenols, antibiotics, anticancer, antiviral, anti-inflammatory as well as

\begin{tabular}{|c|}
\hline Keywords \\
\hline $\begin{array}{l}\text { Cyanobacteria, } \\
\text { Fischerella, GC- } \\
\text { MS, Anti-diabetic, } \\
\text { Anti-cancer }\end{array}$ \\
\hline Article Info \\
\hline $\begin{array}{l}\text { Accepted: } \\
\text { 26 December } 2017 \\
\text { Available Online: } \\
\text { 10 January } 2018\end{array}$ \\
\hline
\end{tabular}
pharmaceuticals. These compounds are reported to be used in agriculture, biology and medicine. This study was performed to isolate Fischerella sp, from river Nile/ Egypt. Also, its potential to produce some bioactive compounds was evaluated. Results indicated that Fischerella BS1-EG isolate during this study has a considerable antifungal activity against Aspergillus, Fusarioum and Penicillum sp. In general, the determined fungal activities by means of inhibition zone ranged between $8.5-16 \mathrm{~mm}$. Regarding the cell cytotoxicity of Fischerella BS1-EG on liver cancer (HepG-2), lung cancer (A549), colon cancer (HCT116), breast cancer (MCF-7) data revealed that Fischerella BS1-EG crude extract exhibited a variable influence on all tested cell lines GC-MS analysis showed that 29 different compounds were detected and identified as fatty acids, alkaloids, phenols, amino acids, the most important 9 compounds were identified as anticancer, antimicrobial, antiinflammatory agents. On the other hand, Fischerella BS1-EG proved to have anti hyper glycemia activity through inhibition of $\alpha$-glucosidase activity. These results may indicate that, for the first time, Fischerella BS1-EG is recorded to have different biological activities as anti-cancer as well as anti-hyperglycemia.
\end{abstract}

\section{Introduction}

Cyanobacteria, a promising photo auto trophic prokaryote, found in various freshwater and marine environments, is now well recognized as bio source of several pharmaceutical compounds. These compounds are necessary for treatment of different human diseases and disorders. In this respect, many species of cyanobacteria are known to have important role in treatment of various human diseases e.g. antibacterial (Burja et al., 2001), anti-HIV (Rajeev and $\mathrm{Xu}, 2004$ ), anti-fungal (Burja et al., 2001), anti-inflammatory (Shizuma, 2003), anti-oxidant and coenzyme (Plavisc et al., 2004), and anti-diabetic (Priatni et al., 2016). It is reported that, in general, cyanobacteria are still unexplored as natural source offering a large amount of chemicals for original compounds discovery and new drugs (Singh et al., 2005). Traditional antibacterial and anticancer drugs producers 
like Actinomycetes and Hyphomycetes have been in the focus of pharmaceutical research for decades. Since the discovery rate of interesting compounds in these classical source organisms is decreasing, it is time to turn to cyanobacteria and exploit their potential. In this respect, cyanobacteria are well known to produce anti-tumor, anticancer, anti-viral and anti-fungal compounds. Many of the pharmaceutically important compounds in cyanobacteria are peptides, including cyanobacterial toxins and important agents for anti-cancer drugs (Singh et al., 2017). Several authors reported that Fischerella spp. can produce several compounds (Hagmann and Jüttner, 1996 and Ghasemi et al., 2003) and some of these identified substances include fischerindole $\mathrm{L}$ (Park et al., 1992), fischerellin A (Hagmann \& Jüttner, 1996), ambiguine isonitriles A-F (Smitka et al., 1992), ambigol A and B (Falch et al., 1993), and tjipanazole D (Falch et al., 1995).

However, this study was designed to isolate and purify Fischerella from river Nile, Giza, Egypt. Also, the pure culture was characterized and evaluated for its potential capacity to have antifungal, anticancer, antidiabetic activities.

\section{Materials and Methods}

\section{Enrichment culture of water samples for} isolation of Fischerella

Two water samples were collected from intake site of drinking water station, Giza, Egypt. Liquid enrichment cultures were prepared from different water samples. Twenty five $\mathrm{ml}$ of water samples were aseptically added to $100 \mathrm{ml}$ of Allen and Arnon broth (Allen and Arnon, 1955) and incubated at $30^{\circ} \mathrm{C}$ under continuous illumination, with Philips Fluorescent white lamps, at a relatively low light intensity (300 -400 lux).

\section{Purification and identification of Fischerella isolates}

The isolated Ficherella, were successively subcultured several times on Allen and Arnon medium and incubated for $3-4$ weeks at $30^{\circ} \mathrm{C}$ until the healthy and homogenous culture were obtained. All isolates were subjected to purification applying several successive transfers, single filament isolation and UV exposure (Higazy, 1985). After wet mount preparation, the Fischerella morphotypes such as filamentous nature, size, shape of vegetative cells, presence of heterocyst and akinetes as well as cell branching were identified and photographed using light microscope (Rippka et al., 1979). In addition, pigment composition of all isolates was determined.

\section{Pigments contents}

Total chlorophyll and total carotenoids were measured using spectrophotometer (Jenway, $6405 \mathrm{UV} / \mathrm{vis})$ at (468 and $666 \mathrm{~nm}$, respectively) according to Seely et al., (1972). The total chlorophyll and total carotenoids concentrations were calculated with the following equations:

Total chlorophyll $\left(\mathrm{mg}^{-1}\right)=\mathrm{OD}_{666} \times \mathrm{D} \times \mathrm{F}$

Where, $\mathrm{E}_{666}=$ the reading at $666 \mathrm{~nm}, \mathrm{D}=$ volume of extract/volume of sample, $\mathrm{F}=11.3$ (factor to equal the reduction in absorbance).

Total carotenoids $\left(\mathrm{mg} \mathrm{l}^{-1}\right)=\mathrm{OD}_{468} \times \mathrm{D} \times \mathrm{F}$

Where, $\mathrm{E}_{468}=$ the reading at $468 \mathrm{~nm}, \mathrm{D}=$ volume of extract/volume of sample, $\mathrm{F}=4.5$ (factor to equal the reduction in absorbance).

Regarding Phycobiliproteins determination, cultures were sonicated for 40 seconds to break up filaments and release the water phycobiliproteins pigments, followed by 
centrifugation at $8000 \mathrm{rpm}$ to remove filament debris (Moares et al., 2010). The optical density (OD) of the supernatant was measured at different wavelengths e.g. 562, 615 and 652 $\mathrm{nm}$ for phycoerythrin, phycocyanin and allophycocyanin, respectively. Phycobiliproteins concentration was calculated according to the following equations in $\mu \mathrm{g} \mathrm{ml}^{-1}$ according to Bennett and Bogard (1973).

Phycocyanin $(\mathrm{PC})=\mathrm{OD}_{615}-0.474\left(\mathrm{OD}_{652}\right) /$ 5.34
Allophycocyanin
$(\mathrm{APC})=\mathrm{OD}_{652}-0.208$
$\left(\mathrm{OD}_{615}\right)$ / 5.09

Phycoerythrin $(\mathrm{PE})=\mathrm{OD}_{562}-2.41(\mathrm{PC})-$ 0.849(APC) / 9.62

\section{Studying the antifungal activity}

\section{Preparation of microalgae extracts}

At the stationary phase of growth, 30 days old, Fischerella culture of each species was harvested and dried in a hot air oven at $50^{\circ} \mathrm{C}$ over night. The dried biomass $(5 \mathrm{~g})$ extracted with different solvent of aqueous, methanol, ethanol, acetone, chloroform, diethyl ether, ethyl acetate and hexane (HPLC grade). The extracts were sonicated for 20 min using ultrasonic microtip probe of 400 watt and centrifuged at $4500 \mathrm{rpm}$ for $10 \mathrm{~min}$. Supernatant was retained and the pellet was re-extracted as before three times. Combined supernatant was evaporated to dryness at $40^{\circ} \mathrm{C}$ using rotary evaporator. Dried extracts were stored in labeled sterile vials in a refrigerator till further use (Chauhan et al., 2010).

\section{Anti-fungal assay}

Different fungal species were used for antifungal assay: Aspergillus flavus NRRL 3357, A. ochraceus ITAL 14, A. carbonarus
ITAL 204, Fusarium verticelloides ITEM 10027 and Penicillium verrucosum BFE 500. The fungal isolates were obtained from Applied Mycology Dept., Cranfield Univ., UK. The stock cultures were grown on potato dextrose agar slant at $30^{\circ} \mathrm{C}$ for 5 days and then kept in refrigerator till use.

\section{Media used for anti-fungal assay}

Potato dextrose agar, PDA medium (ATCC, 1984).

Yeast extract sucrose agar (YES medium) (Tsubouchi et al., 1987).

\section{Disc diffusion assay}

The fungal strains were plated onto potato dextrose agar (PDA) and incubated for 5 days at $25^{\circ} \mathrm{C}$. The spore suspension of each fungus was prepared in $0.01 \%$ Tween 80 solution. The fungal suspension was compared with the 0.5 McFarland standard, the turbidity of the inoculum suspension represented approximately $2 \times 10^{8} \mathrm{cfu} \mathrm{ml}^{-1}$. Similar to antibacterial test, sterilized filter paper discs $(6$ $\mathrm{mm}$ ) were loaded with the extracts and dried completely under sterile conditions. Petri dishes of YES medium were inoculated with $50 \mu 1$ of each fungal culture and uniformly spread using sterile L- glass rod.

The extract loaded discs were placed on the seeded plates by using a sterile forceps. Negative control was prepared by using DMSO and the commercial fungicide Nystatin (1000 Unit $\mathrm{ml}^{-1}$ ) was used as a positive control. The inoculated plates were incubated at $30^{\circ} \mathrm{C}$ for $24-48 \mathrm{~h}$. At the end of the period, antifungal activity was evaluated by measuring the zone of inhibition $(\mathrm{mm})$ against the tested fungus (Medeiros et al., 2011). All treatments consisted of three replicates and the averages of the experimental results were calculated. 


\section{Anticancer assay}

Cell cytotoxicity / viability of Fischerella extract were estimated on liver (HepG-2), lung (A549), Colon (HCT-116) and breast (MCF-7) cell lines applying neutral red uptake assay of Guillermo et al., (2008). Results were obtained by measuring the OD of neutral red extract at $540 \mathrm{~nm}$ in a microtiter plate reader spectrophotometer, using blanks which contain no cells as a reference.

\section{GC -MS analysis}

At the stationary phase of growth, 30 days old, Fischerella culture was harvested and dried in a hot air oven at $50^{\circ} \mathrm{C}$ over night. The dried biomass (5g) extracted with solvent chloroform (HPC grade). The chemical composition of samples extract were performed using Trace GC Ultra-ISQ mass spectrometer (Thermo Scientific, Austin, TX, USA) with a direct capillary column TG-5MS (30 m x $0.25 \mathrm{~mm} \times 0.25 \mu \mathrm{m}$ film thickness). The column oven temperature was initially held at $50^{\circ} \mathrm{C}$ and then increased by $5^{\circ} \mathrm{C} / \mathrm{min}$ to $180^{\circ} \mathrm{C}$ withhold $3 \mathrm{~min}$ then to $280^{\circ} \mathrm{C}$ by $10^{\circ} \mathrm{C} / \mathrm{min}$ withhold $5 \mathrm{~min}$. The injector temperature was kept at $250^{\circ} \mathrm{C}$. Helium was used as a carrier gas at a constant flow rate of $1 \mathrm{ml} / \mathrm{min}$.

The solvent delay was $2 \mathrm{~min}$ and diluted samples of $1 \mu \mathrm{l}$ were injected automatically using Auto sampler AS3000 coupled with GC in the split mode. EI mass spectra were collected at $70 \mathrm{eV}$ ionization voltages over the range of $\mathrm{m} / \mathrm{z} 40-650$ in full scan mode.

The ion source and transfer line temperatures were set at 200 and $250^{\circ} \mathrm{C}$ respectively. The components were identified by comparison of their retention times and mass spectra with those of WILEY 09 and NIST 11 mass spectral database. The GC-MS experiments were performed in GC-MS lab., Atomic and
Molecular Physics Unit, Nuclear Research Center, Egyptian Atomic Energy Authority.

\section{$\alpha$ - Glucosidase inhibitory assay}

The influence of Fischerella BS1-EG on $\alpha$ glucosidase activity was determined according to the method of Kim et al., (2005). The $\alpha-$ glucosidase was determined by measuring the yellow-colored paranitro phenol released from pNPG (the substrate solution p-nitrophenyl gluco pyranoside) at $405 \mathrm{~nm}$. The results were expressed as percentage of the blank control.

Percentage of inhibition is calculated as follows:

$\%$ Inhibition $=\frac{a b s \text { control-abs extract }}{a b s \text { control }} \times 100$

\section{Results and Discussion}

The enrichment culture of water samples indicated the considerable presence of different species of cyanobacteria, with relative abundance of Fischerella. Such Fischerella culture was subjected to purification and characterization studies. Results indicated that characters of all obtained culture of Fischerella are similar to that described by Rippka et al., (1979).

Due to its rapid growth and recovery from UV treatment, as well as its healthy appearance, one isolate was selected and named Fischerella BS1-EG. The vegetative cells divide in more than plane to produce a mature trichome with the lateral branches. The heterocyst is terminal or lateral. Hormogonia composed from small cylindrical cells which enlarge and become rounded (Fig 1.). Concerning the ecological distribution of Fischerella, it is reported that it is mostly found in both terrestrial and aquatic environments (Uyeda et al., 2016) 
At the same time, date revealed that pigment composition of Fischerella BS1-EG culture was as follows:

4.06 and $0.70 \mathrm{mg} \mathrm{g}^{-1}$ for total chlorophyll and total carotenoid, respectively. Also, it contains (mg g ${ }^{-1}$ culture) 47.49, 58.86 and 32.37 of phycocyanin, allophycocyanin and phycoerthrin, in that order.

Concerning the antifungal activity of Fischerella BS1-EG culture against each of Asperigillus flavus, A. ochraceus, A. carbonarus, Fusarium verticelloides, Penicillium verrucosum, several solvents were used to extract all the compounds responsible for such activity. Results in Table (1) revealed that chloroform and aqueous solvents were the best in respect to extraction of antifungal compounds. For example, Fischerella BS1EG extracts showed the highest fungal activities by means of inhibition averages zones using both chloroform and aqueous solvents ranged between 9.7-16.0 $\mathrm{mm}$ and 8.5$12.3 \mathrm{~mm}$ respectively.

Similarly, Devi and Mehta (2016) indicated that Fischerella ambigua extracts showed antifungal activities on different Fusarium species. They added that DCM: ISO extract (Dichloromethane: isopropanol) 1:1 of $F$. ambigue resulted in the maximum inhibition zones of 8.0 and $3.34 \mathrm{~mm}$ in Fusarium undum and $F$. culmorum, respectively. Also Becher and Juttner (2006) have found antifungal compounds such as hapalindol $\mathrm{G}$ and $\mathrm{H}$ from the extract of Fischerella $s p$ which exhibited antifungal activities.

Concerning cell cytotoxicity of Fischerella BS1-EG on liver cancer (HepG-2), lung cancer (A549), Colon cancer (HCT-116) and breast cancer (MCF-7), data pointed out that Fischerella BS1-EG crude extract recorded a pronounced influence on all tested cell lines, The response of such cell lines toward treatment with Fischerella BS1-EG extracts by means of viability percentage could be arranged as follows: on Liver cancer (HepG2)> lung cancer (A549)> colon cancer (HCT116) >breast cancer (MCF-7). This may indicate the anticancer effect of Fischerella on various cancer diseases. Similar findings were obtained by Acuna et al., (2015) when they suggested that the indole alkaloids from Fischerella ambgue showed significant activity against Estrogen sensitive breast cancer cells.

In addition, the chemical composition of Fischerella BS1-EG extract was determined using trace GC Ultra-ICQ mass spectrometer (Fig.2). Also results in Table (3), showed that 29 different compounds were detected and identified as fatty acids, alkaloides, phenols and amino acids. In regard to their biological activities, the most important 9 compounds with relative percentage are presented In Table (4). Data indicated that such compounds have variable effects including, anti-tumor, anticancer, anti-inflammatory, anti-oxidant and anti-microbial activities. e.g. heptadecan, hexadecanoic acid, phytol, hexadecaonoic acid methyl ester, 10-octadecanoic acid methyl ester, octadecanoic acid methyl ester, 1,4benzenediol 2-(1,1-Dimethyle Thyl)-5-(2Propenyl), 9- octodecanoic acid (Z), hexadecanoic acid ethyl ester and eicosan. Cyanobacteria and algae are the immense sources of several metabolites such as alkaloids, carbohydretes, flavonoids, pigments, phenols, steroids, vitamins which can be utilized in biotechnology and industrial fields (Guiheneuf et al., 2016) as well as pharmacological areas including production of several bioactive metabolites that showed antibacterial (Melathi et al., 2014).

Anti-cancer (Semary and Fouda, 2015), antifungal (Shaieb et al., 2014), anti-viral (Abdo et al., 2012) activities which led to remarkable interest in cyanobacterial and algal 
secondary metabolites. Therefore and due to their high pharmaceutical value, a new point of view of exploiting cyanobacteria increased progressively.

During this study, different compounds were found in Fischerella BS1-EG extracts and identified by GC-MS. The most important compounds represented various bioactive metabolites with different biological activities. For example, eicosan $(0.62 \%)$ was reported to have antibacterial, antitumor and cytotoxic effect (Belkhdar et al., 2015). Devi and Mehta (2016), indicated that heptadecane (17.02\%) was found in $F$. ambigua extract and it is known for its anticancer, antioxidant and antimicrobial activities. In addition, it has been demonstrated that a little is known about the mechanisms by which olic acid could affect cell proliferation and cell death of the cancer cells. Therefore, further studies are required to fully clarify the pathway by which olic acid could reduce cancer risk, (Carillo et al., 2012). However, Mericli et al., (2017) showed that both olic acid (1.52\% in this study) and palmitic acid (9.18\% in this study) may have anticancer and anti-proliferative effects on colon cancer cells through signallity pathway and, therefore, they could be potential novel therapeutic agents.

Table.1 Antifungal activity (inhibition zone in $\mathrm{mm}$ ) of Fischerella $\mathrm{Bg} 1 / \mathrm{EG}$ strain crude extracts applying different solvents

\begin{tabular}{|l|c|c|c|c|c|}
\hline \multirow{2}{*}{$\begin{array}{l}\text { Fungi } \\
\text { Culture }\end{array}$} & $\begin{array}{c}\text { A p p li e d } \\
\text { S o l v e n t s }\end{array}$ \\
\hline & Hexane & Chloroform & DEE* & Methanol & Aqueous \\
\hline A. flavus & $8.3 \pm 0.57$ & $9.8 \pm 0.58$ & $8.0 \pm 1.00$ & $8.5 \pm 1.80$ & $8.5 \pm 0.50$ \\
\hline A. ochraceus & $7.7 \pm 0.76$ & $9.7 \pm 0.29$ & $8.8 \pm 0.28$ & $7.5 \pm 0.50$ & $11.2 \pm 1.25$ \\
\hline A. carbonarus & $13.5 \pm 1.32$ & $16.0 \pm 0.50$ & $13.2 \pm 1.04$ & $13.5 \pm 1.80$ & $12.2 \pm 1.53$ \\
\hline F. verticelloides & $14.7 \pm 1.75$ & $10.3 \pm 0.76$ & $9.5 \pm 0.50$ & $11.0 \pm 1.5$ & $10.3 \pm 1.04$ \\
\hline P. verrucosum & $8.2 \pm 1.15$ & $9.7 \pm 0.29$ & $9.3 \pm 1.04$ & $7.8 \pm 0.76$ & $12.3 \pm 1.75$ \\
\hline
\end{tabular}

*DEE, diethyl ether

Table.2 Anti-cancer activity as viability of human cell lines after treatment with Fischerella crude extract

\begin{tabular}{|c|c|c|c|c|}
\hline Extract & \multicolumn{4}{|c|}{$\begin{array}{c}\text { Viability \% } \\
\text { Cell line }\end{array}$} \\
\hline $\begin{array}{l}\text { Concentrati } \\
\text { on }(\mu \mathrm{g} / \mathrm{ml})\end{array}$ & $\begin{array}{c}\text { Liver cancer } \\
\text { (HepG-2) }\end{array}$ & $\begin{array}{l}\text { Lung } \\
\text { cancer } \\
\text { (A549) }\end{array}$ & $\begin{array}{l}\text { Colon cancer } \\
\text { (HCT-116) }\end{array}$ & $\begin{array}{c}\text { Breast cancer } \\
\text { (MCF-7) }\end{array}$ \\
\hline 20 & 214 & 360 & 570 & 645 \\
\hline 40 & 8.3 & 30.6 & 19.0 & 50.5 \\
\hline 80 & 0.0 & 14.6 & 11.9 & 47.8 \\
\hline $\begin{array}{l}\text { IC50 } \\
\quad(\mu \mathrm{g} / \mathrm{ml})\end{array}$ & 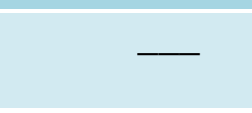 & 16.5 & 15.8 & 63.8 \\
\hline
\end{tabular}


Table.3 Compounds identified from GC-MS analysis of chloroform extract of Fischerella BS1-EG.

\begin{tabular}{|c|c|c|c|c|c|}
\hline $\begin{array}{l}\text { S. } \\
\text { No. }\end{array}$ & Name of Compound & $\begin{array}{l}\text { Molecular } \\
\text { Formula }\end{array}$ & $\begin{array}{c}\text { Molecular } \\
\text { weight }\end{array}$ & RT & Area \% \\
\hline 1. & Decane, 1,1' 1,1'-Oxybis & $\mathrm{C} 2 \mathrm{OH} 42 \mathrm{O}$ & 298 & 13.10 & 0.14 \\
\hline 2. & Eicosan & $\mathrm{C} 2 \mathrm{OH} 42$ & 282 & 14.30 & 0.62 \\
\hline 3. & Hexadecane & $\mathrm{C} 16 \mathrm{H} 34$ & 226 & 15.66 & 0.81 \\
\hline 4. & 2-Decanal E & $\mathrm{C} 10 \mathrm{H} 18 \mathrm{O}$ & 154 & 18.89 & 2.44 \\
\hline 5. & 1-Tetradecanol & $\mathrm{C} 14 \mathrm{H} 30 \mathrm{O}$ & 214 & 19.13 & 0.91 \\
\hline 6. & Pentacosane & $\mathrm{C} 25 \mathrm{H} 52$ & 352 & 20.31 & 0.48 \\
\hline 7. & Heptadecan & C17H36 & 240 & 20.52 & 17.02 \\
\hline 8. & Heptadecane, 7-Methyl- & C18H38 & 254 & 21.35 & 13.92 \\
\hline 9. & 1-Hexadecanol, 2-Methyl- & $\mathrm{C} 17 \mathrm{H} 36 \mathrm{O}$ & 256 & 20.78 & 1.02 \\
\hline 10 & 7-Hexadecenal, (Z)- & $\mathrm{C} 16 \mathrm{H} 30 \mathrm{O}$ & 238 & 22.73 & 1.61 \\
\hline 11. & Docosane & $\mathrm{C} 22 \mathrm{H} 46$ & 310 & 23.49 & 1.14 \\
\hline 12. & 1-Chlorooctadecane & $\mathrm{C} 18 \mathrm{H} 37 \mathrm{Cl}$ & 288 & 24.23 & 0.54 \\
\hline 13. & $\begin{array}{l}\text { 9,12,15-Octadeca Trienoic Acid, } \\
\text { 2-(Acetyloxy)-1-[(Acetyloxy)Met } \\
\text { HYL]ETHYL ESTER, (Z,Z,Z)- }\end{array}$ & $\mathrm{C} 25 \mathrm{H} 40 \mathrm{O} 6$ & 436 & 25.37 & 0.21 \\
\hline 14. & Dodecanoic Acid, 3-Hydroxy & $\mathrm{C} 12 \mathrm{H} 24 \mathrm{O} 3$ & 216 & 25.67 & 0.59 \\
\hline 15. & $\begin{array}{l}\text { 2-Aminoethaneth Iol Hydrogen } \\
\text { Sulfate (Ester) }\end{array}$ & C2H7NO3S2 & 157 & 25.78 & 0.24 \\
\hline 16. & 2,2-Dideutero Octadecanal & C18H34D2O & 270 & 25.85 & 0.13 \\
\hline 17 & 2,2,3,3,4,4 Hexadeutero Octadecanal & C18H30D6O & 274 & 26.96 & 0.29 \\
\hline 18. & $\begin{array}{l}\text { Aspidospermidin 17-Ol 1-Acetyl- } \\
\text { 19,21-Epoxy-1 5,16-Dimethoxy- }\end{array}$ & $\mathrm{C} 23 \mathrm{H} 30 \mathrm{~N} 2 \mathrm{O} 5$ & 414 & 27.20 & 0.29 \\
\hline 19. & 9- Octodecanoic acid (Z) & $\mathrm{C} 18 \mathrm{H} 34 \mathrm{O} 2$ & 282 & 27.80 & 1.52 \\
\hline 20. & Hexadecaonoic Acid Methyl Ester. & $\mathrm{C} 17 \mathrm{H} 34 \mathrm{O} 2$ & 270 & 30.79 & 3.07 \\
\hline 21. & Hexadecanoic Acid, Ethyl Este. & $\mathrm{C} 18 \mathrm{H} 36 \mathrm{O} 2$ & 298 & 31.49 & 0.86 \\
\hline 22. & [1,1'-Bicyclopropyl]-2 Octanoic Acid & $\mathrm{C} 21 \mathrm{H} 38 \mathrm{O} 2$ & 322 & 32.35 & 0.21 \\
\hline 23. & $\begin{array}{l}\text { 2'-Hexyl-, Methyl Ester 1,4- } \\
\text { Benzenediol2-(1,1-DimethyleThyl)- } \\
\text { 5-(2-Propenyl). }\end{array}$ & $\mathrm{C} 13 \mathrm{H} 18 \mathrm{O} 2$ & 206 & 32.45 & 1.74 \\
\hline 24. & OctadecanoicAcid, methylEster. & $\mathrm{C} 19 \mathrm{H} 38 \mathrm{O} 2$ & 298 & 34.47 & 1.77 \\
\hline 25. & 10-Octadecenoic acidMethyl Ester. & $\mathrm{C} 19 \mathrm{H} 36 \mathrm{O} 2$ & 296 & 34.81 & 2.6 \\
\hline 26. & 7-Methyl-Z-Tetradecen1-Ol Acetate. & $\mathrm{C} 17 \mathrm{H} 32 \mathrm{O} 2$ & 268 & 36.23 & 0.36 \\
\hline 27. & Alanine,3-(Benzyloxy)-, L- & $\mathrm{C} 10 \mathrm{H} 13 \mathrm{NO} 3$ & 195 & 36.48 & 0.61 \\
\hline 28. & Phytol. & $\mathrm{C} 20 \mathrm{H} 40 \mathrm{O}$ & 296 & 37.45 & 8.02 \\
\hline 29. & Hexadecanoic Acid . & $\mathrm{C} 16 \mathrm{H} 32 \mathrm{O} 2$ & 256 & 40.08 & 9.18 \\
\hline
\end{tabular}


Table.4 The most important identified compounds from GC-MS analysis of choloroform extract of FischerellaBS1-EG

\begin{tabular}{|c|c|c|c|}
\hline No & $\begin{array}{l}\text { Name of } \\
\text { compound }\end{array}$ & $\begin{array}{l}\text { Compoud } \\
\text { Nature }\end{array}$ & Bioogical Activity \\
\hline 1. & Eicosan & $\begin{array}{l}\text { Alphatic hydro } \\
\text { carbon }\end{array}$ & $\begin{array}{l}\text { Anti-cancer activity against the humangastri cSGC- } \\
7901 \text { cell line, Anti-bacterial, antitumor, antifungal, } \\
\text { cytotoxic. }\end{array}$ \\
\hline 2. & Heptadecan & $\begin{array}{l}\text { Alphatic } \\
\text { hydrocarbon }\end{array}$ & Anti-cancer, anti-bacterial, anti-oxidant. \\
\hline 3. & $\begin{array}{l}\text { 9- Octodecanoic } \\
\text { acid }(\mathrm{Z})\end{array}$ & $\begin{array}{l}\text { olic acid (fatty } \\
\text { acid) }\end{array}$ & Anti-gastric and breast cancer, anti-oxidant \\
\hline 4. & $\begin{array}{l}\text { Hexadecaonoic } \\
\text { acid methyl ester }\end{array}$ & $\begin{array}{l}\text { Palmetic acid } \\
\text { methyl Ester }\end{array}$ & $\begin{array}{l}\text { Anti-bacterial,anti-fungal,anti-oxidant,decrease blood } \\
\text { cholesterol,anti-inflammatory. }\end{array}$ \\
\hline 5. & $\begin{array}{l}\text { 10-octadecenoic } \\
\text { acid methyl ester }\end{array}$ & $\begin{array}{l}\text { Unsaturated } \\
\text { fatty acid, } \\
\text { methyl ester }\end{array}$ & $\begin{array}{l}\text { Anti-bacterial,anti-fungal,anti-oxidant,decrease blood } \\
\text { cholesterol }\end{array}$ \\
\hline 6. & $\begin{array}{l}\text { 1,4-Benzenediol } \\
\text { 2-(1,1-Dimethyle } \\
\text { Thyl)-5-(2- } \\
\text { Propenyl)- }\end{array}$ & Ibuprofen & $\begin{array}{l}\text { Anti-inflammatory agent used in the therapy of } \\
\text { rheumatism and arthritis, analgesic, antipyretic and } \\
\text { platelet-inhibitors. Otherwise called as ibuprofen. }\end{array}$ \\
\hline 7. & $\begin{array}{l}\text { Hexadecanoic acid } \\
\text { ethyle ester }\end{array}$ & $\begin{array}{l}\text { palmetic acid, } \\
\text { ethyle eser }\end{array}$ & $\begin{array}{l}\text { Antioxidant, Hypocholesterolemic, Nematicide, } \\
\text { Pesticide, Antiandrogenic, flavor, Hemolytic } 5 \alpha \\
\text { reductase inhibitor. }\end{array}$ \\
\hline 8. & phytol & Diterpene & $\begin{array}{l}\text { Can be used as a precursor for the manufacture of } \\
\text { synthetic forms of vitamin E and vitamin K1 in } \\
\text { ruminants, anti- bacterial,anti-cancer,cancer } \\
\text { preventive,deuritic, anti-inflammtory. }\end{array}$ \\
\hline 9. & Hexadecanoic acid & palmetic acid & $\begin{array}{l}\text { Anti-human lukemia, Antioxidant, Anti-inflammatory } \\
\text { Antioxidant, Hypocholesterolemic nematicide, } \\
\text { pesticide, anti androgenic, flavor hemolytic, } 5-\alpha \\
\text { reductase inhibitor, potentmosquito larvicide. }\end{array}$ \\
\hline
\end{tabular}

Table.5 Total carbohydrates, exopolysaccharides (Eps) and anti-diabetic Activity of aqueous extract of Fischerella BS1-EG

\begin{tabular}{ll}
\hline Determination & FischerellaBS1-EG
\end{tabular}

Total carbohydrates \% 32

EPS $(g)$

Inhibition of $\alpha$-glucosidase \% Water extract
22

7.56 
Fig.1 Light micrographs (a: $100 \mathrm{x}, \mathrm{b}$ : 600x) and liquid cultures (c and d) of 30 days old cultures of Fischerella Bs1- EG

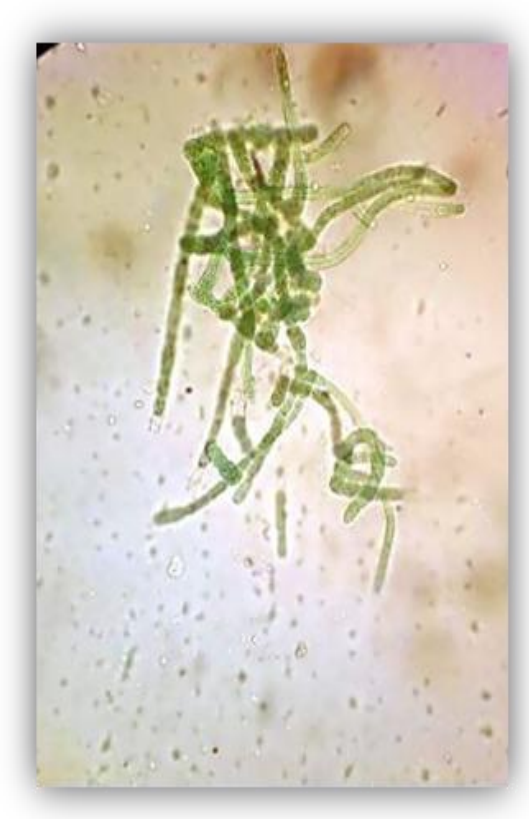

(A)

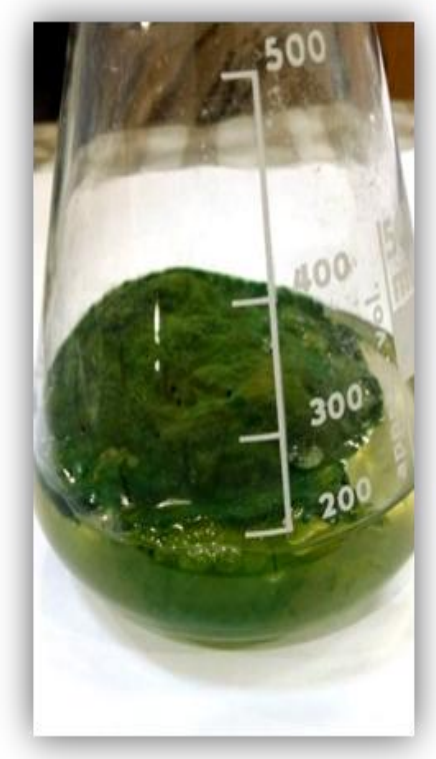

(C)

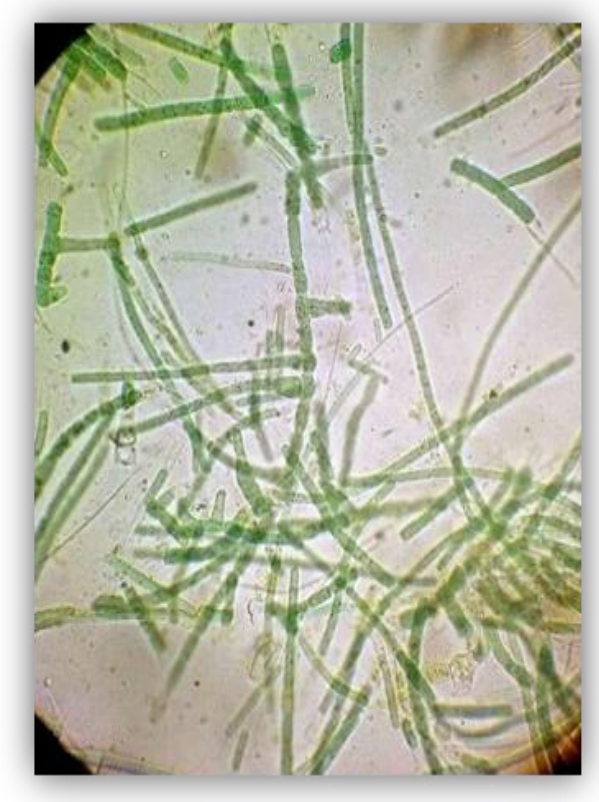

(B)

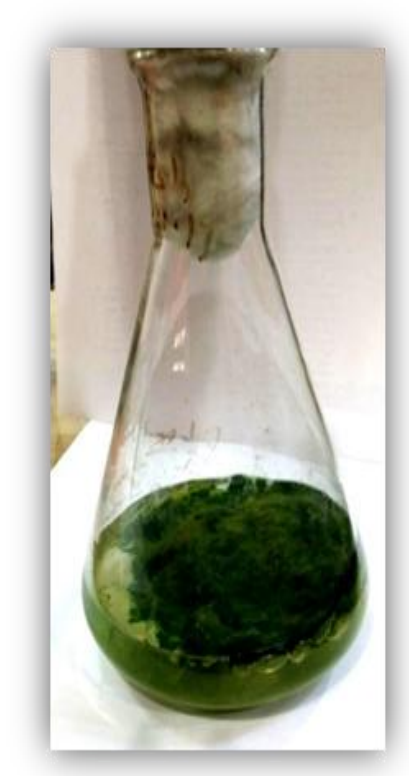

(D) 
Fig.2 Chromatogram of chloroform extract of Fischerella BS1-EG

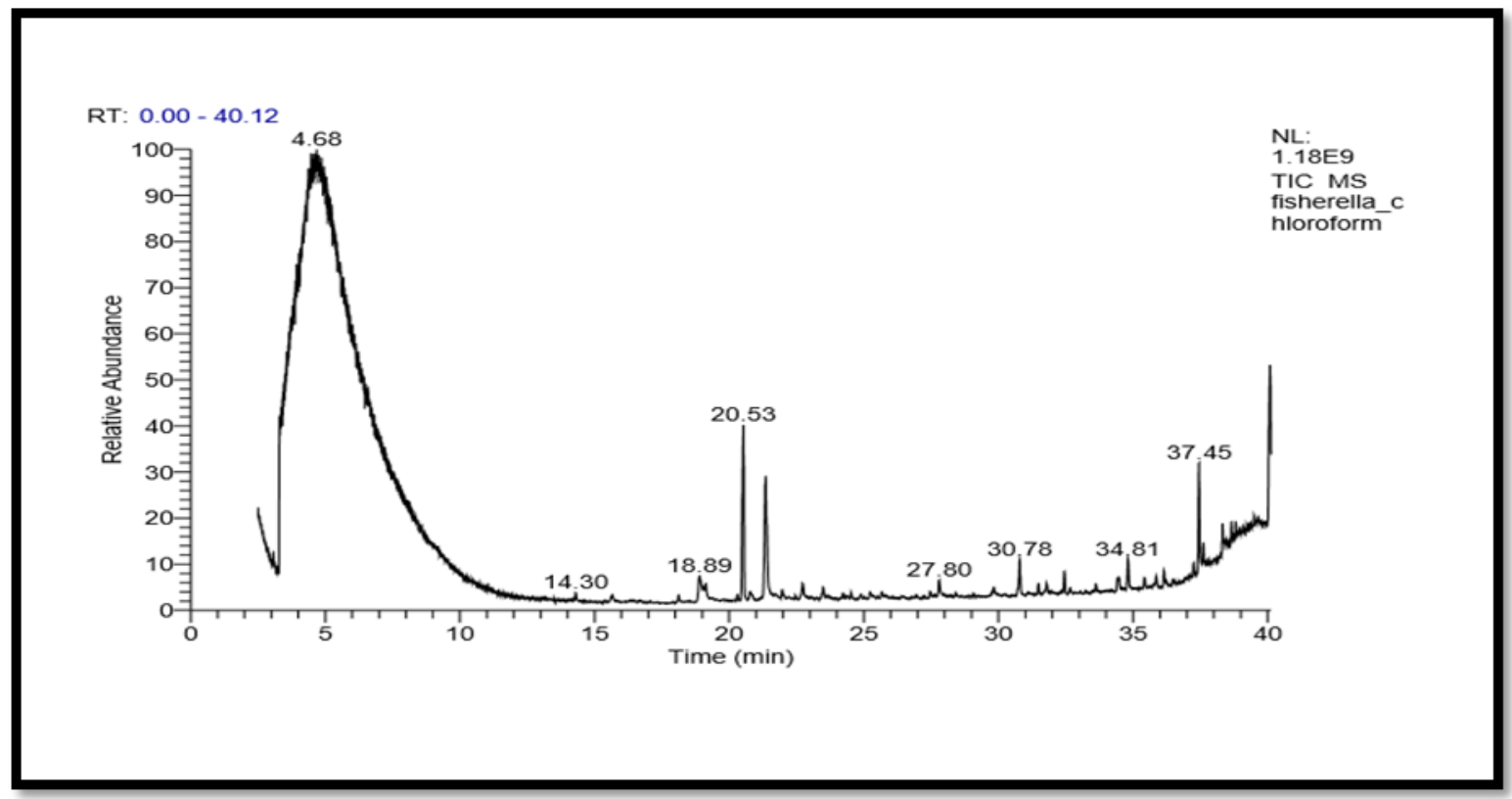

At the same time, it is concluded from results of this study that Fischerella BS1-EG produced hexadecanoic acid $(0.86 \%)$. This compound was also produced from ethanol extract of the aquatic plant Eichormia crassipon and proved to have anti-androgenic effect (Tyagi and Agarwal, 2017). Meanwhile, Gillat (2006) reported that antiandrogen are used in treatment of prostate cancer and prostate enlargement in male as well as treatment of acne, and polycystic ovary syndrome in females.

Meanwhile, phytol was detected in Fischerella BS1-EG extract (8.02\%) and was reported to be used as a precursor for the manufacture of synthetic forms of vitamin $\mathrm{E}$ (Netscher, 2007) and Vitamin K (Daines et al., 2003). Recently, phytol was found to act as anti-inflammatory anti-cancer (Tyagi and Agarwal, 2017) and improve immunological response against tumor in a very beginning stage of carcinogenesis (Singh et al., 2017). Additionally, Data revealed that ibuprofen, 10-octadecanoic acid methyl ester and hexadecanoic acid methyl ester were detected in Fischerella BS1-EG extracts with considerable concentration i.e. 1.74, 2.60 and $3.07 \%$. These compounds were previously reported to have anti-inflammatory, antioxidant, and antifungal activities (Belkhdar et al., 2015).

On the other hand, anti-diabetic activity of FischerellaBS1-EGwas estimated by analysis of inhibition percentage of $\alpha$-glucosidase activity. In this respect, data in Table (5) revealed that Fischerella BS1-EG culture had a potential activity on $\alpha$-glucosidase as inhibitor e.g. $7.56 \%$ with total carbohydrates and EPS content of 32\%, 22g in that order.

Results of this study revealed that Fischerella BS1-EG extract exhibited potential activity in alpha-glucosidase inhibition i.e. $7.5 \%$ indicating its anti-diabetic effect (Periatni $e t$ $a l ., 2016)$. It is well known that $\alpha$-glucosidase inhibitors are saccharides that act as competitive inhibitors of enzymes needed to digest carbohydrates specially $\alpha$-glucosidase enzyme formed in the brush border of small intestines. Since $\alpha$-glucosidase inhibitors 
prevent the digestion of carbohydrates, such as starch and table sugar, it is therefore suggested that such inhibitors could be used to reduce the impact of carbohydrates on blood sugar and subsequently decrease the current blood glucose levels in diabetic patients (De Geeter et al., 2014).

Several studies reported that anti-diabetic potential was reported by many plants (Kazeem et al., 2013) and some marine cyanobacteria e.g. Oscillatoria, Lyngbya, Phormidium and Synechococcus. No previous studies were found concerning the antidiabetic activity by any of Fischerella $s p$.

Therefore it could be concluded that results of this study is most likely the first report on the influence of Fischerella $s p$ as a potential agent in the field of human anticancers and anti-diabetic treatment.

\section{References}

Abdo S. M., Mona H. H., Waleed M. E., Rawheya A. S. E. D., Gamila H. A. 2012. Antiviral activity of freshwater algae. J. Appl. Pharm. Sci. 2: 21-25.

Acuña, M. U; Zi, T; Oriala,J. and de Blanco, E.J.C. 2015. Ambiguine I Isonitrile from Fischerella ambigua Induces

Caspase-Independent Cell Death in MCF-7 Hormone Dependent Breast Cancer Cells.nt J Cancer Res (Tortola).49(1): 1655-1662.

Allen, M.B. and Arnon, D.I. 1955. Studies on nitrogen-fixing blue-green algae. I. Growth and nitrogen fixation by Anabaena cvlindrica Lemm. Plant Physiology. 30: 366-372.

ATCC 1984. American Type Culture Collection, $13^{\text {th }}$ ed., USA, 517p.

Becher PG, Juettner F. 2006 Insecticidal activity- a new bioactive property of the cyanobacterium Fischerella. Polish J Ecol; 54: 653-662.

Belkhdar, G.; Benjouad, A.and Abd ennebi,
E.H. 2015. Determination of some bioactive chemical constituents from Thesium Humile Vahl, J.Matar. Environ.Sci., 6(10): 2778-2783.

Bennett, A. and Bogard, L. 1973. Complementary chromatic adaptation in a filamentous blue-green alga. $J$. Filament Biol., 58: 419-438.

Burja, A.M., Banaigs, B., Abou-Mansour, E., Burgess, J.G. and Wright, P.C. 2001. Marine cyanobacteria: A prolific source of natural products. Tetrahedron, 57: 9347-9377.

Carrillo, c; Cavia del M. and Alonso- torre, S.R. 2012. Antitumor effect of oleic Acid mechanisms of action. A review. Nutr. Hosp., 27 (5): 1860-1865.

Chauhan, A.; Chauhan, G.; Gupta, P.; Goyal, P. and Kaushik, P. (2010). In vitro antibacterial evaluation of Anabaena sp. against several clinically significant microflora and HPTLC analysis of its active crude extracts. Indian J. Pharm., 42:105-107.

Daines, Alison; Payne, Richard; Humphries, Mark; Abell, Andrew 2003. The Synthesis of Naturally Occurring Vitamin $\mathrm{K}$ and Vitamin $\mathrm{K}$ Analogues. Current Organic Chemistry, 7(16): 1625-34.

De Geeter, M. and Williamson, B. 2016. Alternative agent in Type 1 Diabetes in Addition to Insulin Therapy: Metformin, Alpha-Glucosidase Inhibitors, pioglitazone, Glp-1 Agonists, Dpp-1V Inhibitors, and SGLT-2 Inhibitors, Joarnal of pharmacy practice, 29 (2): 144-159.

Devi, K.M and Mehta, S. K. 2016. Antimicrobial activity and GC-MS analysis of fresh water Cyanobacterium, Fischerella ambigua Wjpmr, 2(5):199208.

Falch BS, König GM, Wright AD, Sticher O 1993. Ambigol A and B: New biological active polychlorinated 
aromatic compounds from the terrestrial blue-green alga Fischerella ambigua. JOrg Chem 58: 6570-6575.

Falch BS, König GM, Wright AD, Sticher O, Angerhofer CK, Pezzuto JM, Bachmann $\mathrm{H}$ 1995. Biological activities of cyanobacteria: Evaluation of extracts and pure compounds. Planta Med 61: $321-328$

Gillatt, D. 2006. Anderogen treatment in locally advanced prostate cancer: are they all the same?' J.Cancer Res. Clin. Oncol., 1: S17-26.

Guillermo Repetto, Ana del Peso \& Jorge L Zurita, 2008. Neutral red uptake assay for the estimation of cell viability/cytotoxicity, Nature Protocol, 3(7), 1126-1131.

Hagmann L, Jüttner F 1996. Fischerellin A, a novel photosystem-II-inhibiting alleolo chemical of the cyanobacterium Fischerella muscicola with antifungal and herbicide activity. Tetrahedron Lett 37: 6539-6542.

Higazy, A.M. 1985. Asymbiotic $\mathrm{N}_{2-}$ Fixation in Egyptian Aquatic Environment. Ph.D. Thesis, Fac. Agri., Cairo University, p123.

Kazeem, M.I.; Adamson, J.O.; and Ogunwande, I.A. 2013. Modes of inhibition of $\alpha$ - Amylase and $\alpha$ Glucosidase by Aqoueous Extract of Morinda Lucida Benth leaf. Biomed Research International, volume 2013, ID: 527570:1-6.

Kim, Y.M; Jeong, Y.K; Wang, M. H; Lee, W. Y. and Rhee, H.I. 2005. Inhibitiory effect of pine extract on $\alpha$-glucsidase activity and postprandial hyperglucemia. Nutrition, 2 (6): 765761.

Kumar, P.P.; Kumaravel, S.; Lalitha, C. 2010. Screening of antioxidant activity, total phenolics and GC-MS study of Vitex negundo. Afr. J. Biochem. Res., 4, 191195.
Malathi T., Babu M. R., Mounika T., Snehalatha D., Rao B. D. 2014 Screening of cyanobacteria strains for antibacterial activity. Phykos., 44: 6-11.

Mercili, F.; Becer, E.; Kabadayi, H.; Hanogalu, A.; Hanogalu, D.Y; Yauus, D.O; Ozek, T. and Vatansever, S. 2017. Fatty acid Composition and anticancer Activity In colon carcinoma cell lines of Prunus dulcis seed oil. Pharmaceutical Biology, 55 (1): 1239-1248.

Moares, C.; Burkert, M. and Kalil, J. 2010. Cphycocyanin Extraction Process for Large-Scale Use. J. Food Biochem., 34(1):133-138.

Netscher, Thomas 2007. Synthesis of Vitamin $E^{\prime \prime}$ In:. Vitamin E. Vitamins \& Hormones. 76. (Litwack, Gerald, ed.) pp. 155-202. doi:10.1016/S0083. ISBN978- 0-12-373592-8.

Park A, Moore RE, Patterson GML. 1992. Fischerindole L, a new isonitrile from the terrestrial blue-green alga Fischerella muscicola. Tetrahedron Lett., 33: 3257-3260.

Plavsic, M., Terzic, S., Ahel, M. and van den Berg, C.M.G. 2004. Folic acid in coastal waters of the Adriatic Sea. Mar. Freshw. Res., 53: 1245-1252.

Priatni, S.; Budiwwati, T. A.; Ratnaningrum, D.; Kosasih, W.; Anderyani, R.; Susanti, H. and Susilaningsih, D. 2016. Antidiabetic screening of some idonesian marine cyanobacteria collection. Biodiversitas, 17(2):642646.

Raghukumar, C., Vipparty, V., David, J.J. and Chandramohan, D. 2001. Degradation of crude oil by marine cyanobacteria. Appl. Microbiol. Biotechnol., 57: 433436.

Rajeev, K.J. and Xu, Z. 2004. Biomedical compounds from marine organisms. Mar Drugs 2, 123-146.

Rippka, R.; Deruelles, J.; Waterbury, B.; Herdman, M. and Stanier, Y. 1979. 
Generic assignments, strain histories and properties of pure cultures of cyanobacteria. J. Gen. Microbiool., 111:1-61.

Seely, R.; Duncan, J. and Vidaver, E. 1972. Preparative andanalytical extraction of pigments from brown algae with dimethyl sulfoxide. Mar. Biol., 12: 184188.

Semary N. A. E., Fouda M. 2015. Anticancer activity of Cyanothece sp. strain extracts from Egypt: first record. Asian Pac. J. Trop. Biomed. 5, 992-995. 10.1016/j.apjtb.2015.09.004.

Shaieb F. A., Issa A. A., Meragaa A. 2014. Antimicrobial activity of crude extracts of cyanobacteria Nostoc commune and Spirulina platensis. Arch. Biomed. Sci. 2, 34-41.

Shizuma, Y. 2003. Microalgal metabolites. Curr. Opin. Microbiol., 6: 236-243.

Singh, R; Parihar, P; Singh, M; Bajagwz, A; Kumar, J; Singh, S; Singh, P.V. and Prasad, S.M. 2017. Uncovering potential Applications of Cyanobacteria and Algal Medicine Current Status and Future Prospects. Frontiers in Microbiology, 8(article 515): 1-37.

Singh, S., Kate, B.N. \& Banerjee, U.C. 2005. Bioactive critical compounds from cyano-bacterial and microalgae:an overview. Crit. Rev. Biotechnol., 25: 73-95.

Smitka TA, Bonjouklian R, Doolin L, Jones ND, Deeter JB, Yoshida WY, Prinsep MR, Moore RE, Patterson GML, 1992: Ambiguine isonitriles, fungicidal hapalindole-type alkaloids from three genera of blue-green algae belonging to Stigonemataceae. J Org. Chem., 57: 857-861.

Tsubouchi, H.; Yamamoto, K.; Hisada, K.; Sakabe, Y. and Udagawa, S.1987. Effect of roasting on ochratoxin A level in green coffee beans inoculated with Aspergillusochraceus. Mycopathologia, 97: 111-115.

Tyagi, T. and Agarwal, M. 2017. Phytoschemical screening and GC-MS analysis of bioactive consititute in the ethanolic extract of pistia stratiotes L. and Eichhornia crassipes (Mart). solms, Journal of Pharmacognosy and Phytochemistry, 6(1): 195-206

Uyeda, Josef C., Luke J. Harmon, Carrine E. Blank 2016. Comprehensive Study of Cyanobacteria: Morphological and Ecological Evolutionary Dynamics through Deep Geologic Time. Plos One, 11(9): 1-32.

\section{How to cite this article:}

Bassant E. Ahmed, Mona H. Badawi, Soha S. Mostafa and Aziz M. Higazy. 2018. Human Anticancers and Antidiabetic Activities of the Cyanobacterium Fischerella sp. Isolated from River Nile, Egypt. Int.J.Curr.Microbiol.App.Sci. 7(01): 3473-3485.

doi: https://doi.org/10.20546/ijcmas.2018.701.409 